\title{
Comparative study of retaining walls aiming to optimize carbon footprint
}

Urban areas are commonly developed with inadequate planning, which can lead to communities settling in unstable locations, creating a need to either relocate these settlements to more appropriate places, or to stabilize the terrain. These actions must be combined with practices focused on reduction of environmental impacts, such as $\mathrm{CO} 2$ emissions. Therefore, this research aimed to compare the carbon footprint of reinforced soil structures to a conventional method. Two types of retaining wall using geogrid reinforcements were designed as an alternative to a cantilever wall made of reinforced concrete. After the design process, the volume of necessary material was estimated for each structure as well as the amount of $\mathrm{CO} 2$ emissions related to their production. The designed reinforced soil structures obtained a much smaller carbon footprint when compared to the reinforced concrete structure. Due to the increasing demand for terrain stabilization in urban areas, structures that are less impactful to the environment should be prioritized especially when they can also be used to promote vegetation growth. Thus, reinforced soil structures are a great alternative to common methods because of their smaller carbon footprint and they can also bring several benefits to the landscape, such as an increase in vegetated area.

Keywords: Geogrid; Slope; Geomorphology.

\section{Estudo comparativo de estruturas de contenção objetivando otimizar a pegada de carbon}

\begin{abstract}
Áreas urbanas são comumente desenvolvidas com planejamentos inadequados, o que pode acarretar o assentamento de comunidades em locais instáveis, criando a necessidade de relocação dos assentamentos para locais apropriados ou a estabilização do relevo. Essas ações devem ser aliadas a práticas voltadas a diminuição de impactos ambientais como a emissão de $\mathrm{CO}$. Portanto, o presente trabalho teve como objetivo comparar a pegada de carbono de estruturas de solo reforçado com um método convencional. Foram projetados dois tipos de estrutura de contenção com solo reforçado por geogrelhas como alternativa a um muro de flexão de concreto armado. Após o processo de dimensionamento, foi estimado o volume de material necessário para cada estrutura e a quantidade de emissões de CO2 relacionados a sua produção. As estruturas de solo reforçado por geogrelhas obtiveram uma pegada de carbono muito menor quando comparadas ao muro de flexão. Em virtude da crescente demanda da estabilização do relevo em áreas urbanas, estruturas de menor impacto ao meio ambiente devem ser priorizadas especialmente quando possam promover o crescimento da vegetação. Sendo assim, as estruturas de solo reforçado por geogrelhas, são uma grande alternativa de menor pegada de carbono, que podem trazer diversos benefícios a paisagem, como um aumento na área vegetada.
\end{abstract}

Palavras-chave: Geogrelha; Talude; Geomorfologia.

Topic: Tecnologia, Modelagem e Geoprocessamento

Reviewed anonymously in the process of blind peer.
Received: 04/12/2019

Approved: 13/01/2020
João Vitor de Almeida Bezerra (iD

Universidade Federal Rural de Pernambuco, Brasil

http://lattes.cnpq.br/0577287275286569

http://orcid.org/0000-0001-8767-4646

j.vitor.almeida@outlook.com

Tiago Gripp Mota

Universidade Federal Rural de Pernambuco, Brasil

http://lattes.cnpq.br/3716799103728083

http://orcid.org/0000-0002-2015-9196

tiagogripp@yahoo.com.br

Horasa Maria Lima da Silva Andrade (iD

Universidade Federal Rural de Pernambuco, Brasil

http://lattes.cnpq.br/4314101991387960

http://orcid.org/0000-0002-5366-6610

horasaa@gmail.com

\author{
uciano Pires de Andrade (iD) \\ Universidade Federal Rural de Pernambuco, Brasil \\ http://lattes.cnpq.br/5367851306746294 \\ http://orcid.org/0000-0001-5818-711X \\ lucianopandrade@gmail.com \\ Ricardo Brauer Vigoderis \\ Universidade Federal Rural de Pernambuco, Brasil \\ http://lattes.cnpq.br/8447376601980922 \\ http://orcid.org/0000-0001-8775-972X \\ vigoderis@hotmail.com
}

Referencing this:

BEZERRA, J. V. A.; MOTA, T. G.; ANDRADE, H. M. L. S.; ANDRADE, L. P.; VIGODERIS, R. B.. Comparative study of retaining walls aiming to optimize carbon footprint. Revista Ibero Americana de Ciências Ambientais, v.11, n.1, p.460-467, 2020. DOI:

http://doi.org/10.6008/CBPC2179-6858.2020.001.0040 


\section{INTRODUCTION}

Urban expansion in small and medium-sized cities is a phenomenon that has made several remarkable changes to their diverse geophormological environment, affecting their function and rupture limits, leading to rapid consequences to the stability of the landscape (AZAMBUJA et al., 2015). Risks and disasters have become increasingly present in cities, highlighting the challenges faced during the urban development process (MARANDOLA JÚNIOR et al., 2013). The more common disasters that lead to loss of life in Brazil are related to flash floods, floods and landslides, the latter being responsible for $15,60 \%$ of the disasters (UFSC et al., 2013).

The occurrence of landslides can be avoided through the application of an adequate urban planning that aims to prevent communities from settling in unstable zones and to create systems that reduce the impact of erosive processes on unstable slopes that are already occupied. Retaining walls alongside adequate drainage systems can be built in occupied slopes in order to prevent landscapes.

According to Darwin et al. (2016), retaining walls are used to retain landmasses and other loose materials when circumstances prevent these elements to assume their natural form. The Brazilian Technical Standard (NBR) number 11682 written by the Brazilian Association of Technical Standards - ABNT (2006), specifies that retaining walls can be classified on the following groups: cantilever walls, anchored walls, reinforced soil structures, structures for the stabilization of rock slopes and the mixed types.

Cantilever walls are the most common retaining structures for heights ranging from 2.5 to 6 meters, especially due to their simplicity and for their price-performance ratio (HASSOUN et al., 2015). Reinforced soil structures use geosynthetics or metal strips as reinforcements that are embedded in granular backfills and can be divided into two categories: Mechanically Stabilized Earth (MSE) walls and Reinforced Soil Slopes (RSS) (XIAO, 2015).

The stability of reinforced soil slopes can be compromised by erosion from surface runoff, highlighting the need for a system that protects the surface of the slope. Vegetation cover can be used to protect the slope; However, its efficacy is associated to the steepness of the slope (BERG et al., 2009). The possibility to implement vegetation makes reinforced soil slopes a great alternative to other retaining structures since it can lead to a lower impact on the environment as well as bringing several benefits to the landscape.

Despite its importance, the construction sector causes a large number of complex environmental impacts, especially carbon dioxide (CO2) emissions (CHOU et al., 2015), which is one of the gases responsible for the increase of global temperatures through the greenhouse effect. Most of the environmental impacts are directly related to the production of building materials. For this reason, there is an increasing global trend for the proposal of the use of innovative building materials that consider the mitigation of the environmental impacts during their production process. In addition to improving the production process of building materials, improving their management is another key step to reduce the consumption of natural resources (PASSUELLO et al., 2014). 
Considering the aforementioned arguments, this researched aimed to compare, through a modeling process, the environmental cost of the application of reinforced soil structures with a cantilever wall made of reinforced concrete. The carbon footprint was estimated, based on the emissions made during the production process for the materials of each structure.

\section{METHODOLOGY}

A Mechanically Stabilized Earth (MSE) wall and a Reinforced Soil Slope (RSS), both reinforced by geogrids made of polymers, were designed as an alternative to the cantilever wall made of reinforced concrete (Figure 1) proposed by Marchetti (2007) in his book titled Retaining Walls. The structures were designed for a sandy soil slope with a height of 5.5 meters with a surcharge of $25 \mathrm{kN} / \mathrm{m}$. The unit weight of the soil was established as $18 \mathrm{kN} / \mathrm{m}^{3}$, the angle of internal friction as $28^{\circ}$ and the compressive strength of concrete as $20 \mathrm{MPa}$. These were the parameters utilized by Marchetti (2007) for his cantilever wall.

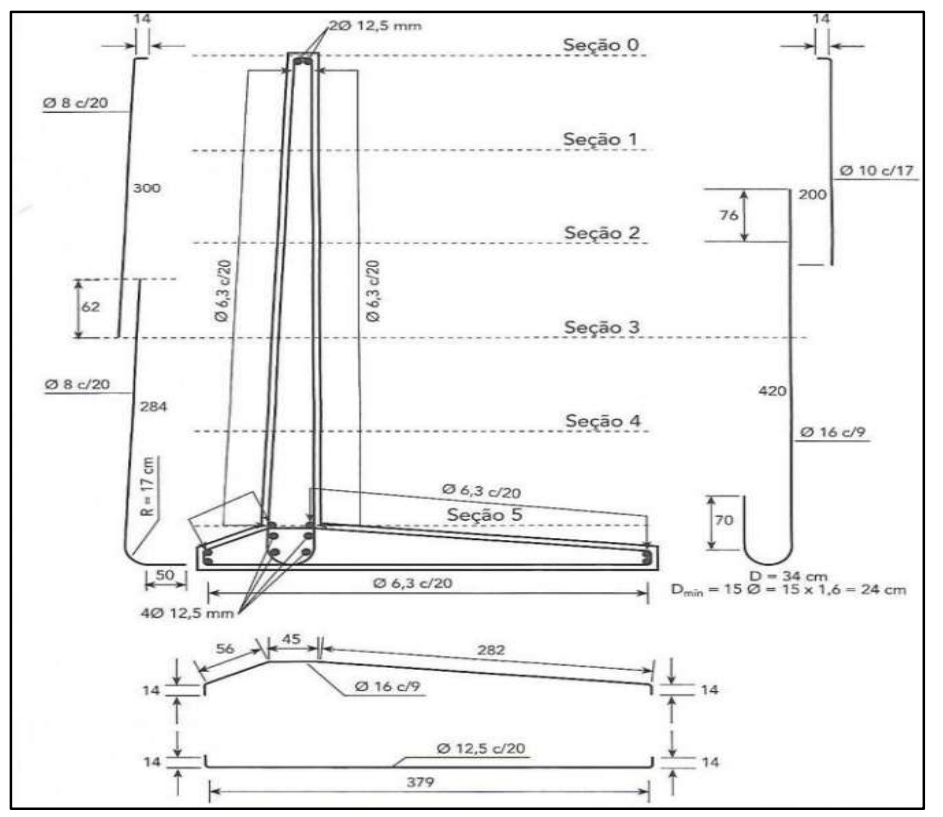

Figure 1: Cantilever wall made of reinforced concrete. Source: Marchetti (2007).

The Coulomb method was used to calculate the active and passive pressures, which according to Xiao (2015) was elaborated in 1766 and utilizes Equations 1 and 2.

$$
\begin{array}{ll}
\mathbf{P}_{\mathbf{a}}=\frac{1}{2} \boldsymbol{\gamma} \mathbf{H}^{2} \mathbf{K}_{\mathbf{a}} & \text { Eq. } 1 \\
\mathbf{P}_{\mathbf{p}}=\frac{1}{2} \boldsymbol{\gamma} \mathbf{H}^{2} \mathbf{K}_{\mathbf{p}} & \text { Eq. } 2
\end{array}
$$

Where, $\boldsymbol{P}_{\boldsymbol{p}}$ and $\boldsymbol{P}_{\boldsymbol{a}}$ are the active and passive pressures, respectively, per length unit of the wall; $\gamma$ is the unit weight of the soil; $\mathrm{H}$ is the height of wall while $\boldsymbol{K}_{\boldsymbol{a}}$ and $\boldsymbol{K}_{\boldsymbol{p}}$ are, respectively, the active and passive pressure coefficients for the Coulomb method.

\section{Design of the geogrids}

The structures designed in this research used geogrids made of polymers as reinforcement. The 
design process was performed with support of the software Geo5 - Slope Stability and through Equation 3 which according to Xiao (2015) is used to calculate the strength of the geogrids.

$$
\mathbf{T}_{\mathrm{al}}=\frac{\mathrm{T}_{\mathrm{ult}}}{\mathbf{F S} * \mathrm{RF}_{\mathrm{ID}} * \mathbf{R F}_{\mathrm{CR}} * \mathbf{R F}_{\mathrm{CBD}}}
$$

Where,

FS is the factor of safety that can be 1.5 for granular soils or 2.0 for cohesive soils;

$\boldsymbol{T}_{\boldsymbol{a l}}$ is the allowable tensile strength;

$\boldsymbol{T}_{\boldsymbol{u l t}}$ is the ultimate tensile strength;

$\boldsymbol{R} \boldsymbol{F}_{\boldsymbol{I D}}$ is the reduction factor for installation damage;

$\boldsymbol{R} \boldsymbol{F}_{\boldsymbol{C} \boldsymbol{R}}$ is the reduction factor for creep;

and $\boldsymbol{R} \boldsymbol{F}_{\boldsymbol{d}}$ the reduction factor for chemical and biological degradation, also called durability reduction factor.

For the design process a value of 2 was used for $\boldsymbol{R} \boldsymbol{F}_{\boldsymbol{C} \boldsymbol{R}}$ and $\boldsymbol{R} \boldsymbol{F}_{\boldsymbol{d}}$ while $\boldsymbol{R} \boldsymbol{F}_{\boldsymbol{I D}}$ was considered to be 1.5 since these were the average values proposed by Leshchinsky $(2002$, cited by XIAO, 2015) for geogrids made of polymers. FS was considered as 1.5 since the backfill soil is granular.

\section{Estimating $\mathrm{CO}_{2}$ emissions}

After the design process it was possible to estimate the necessary volume of building materials for each structure. Through the volume, it was possible to estimate the $\mathrm{CO}_{2}$ emissions using reference values from the related scientific literature that establishes values as a function of material volume $\left(\mathrm{m} 3 / \mathrm{CO}_{2}\right)$. For the cantilever wall made of reinforced concrete proposed by Marchetti (2007), a reference value of 113,52 $\mathrm{KgCO}_{2} / \mathrm{m}^{3}$ was used which was proposed by Santoro et al. (2016) to produce concrete with a compressive strength of $20 \mathrm{MPa}$. For the steel used in the structure a value of $1,74 \mathrm{KgCO}_{2} / \mathrm{Kg}$ was used which was tabulated by the Inventory of Carbon \& Energy (ICE) V2.0 written by Hammond et al. (2011). For the reinforced soil structures a value of $2,97 \mathrm{KgCO}_{2} / \mathrm{Kg}$ was used which was proposed by Raja et al. (2015) for extruded geogrids. Figure 2 is a flowchart illustrating the methodology of this research.

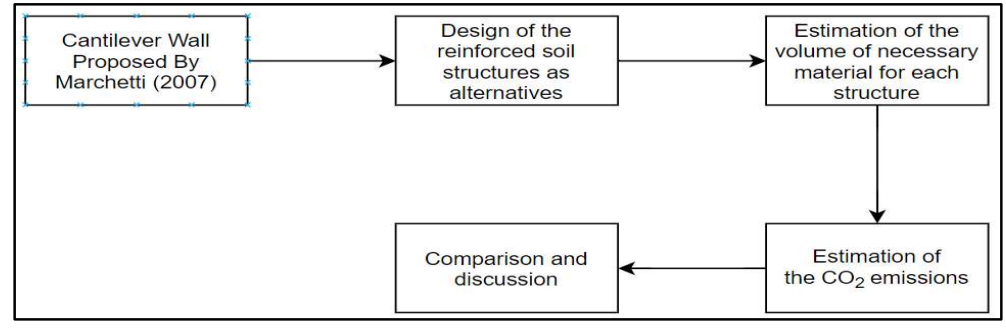

Figure 2: Flowchart illustrating this research`s methodology

\section{RESULTS AND DISCUSSION}

The design process of the Reinforced Soil Slope (RSS) resulted in a structure of 3 meters of length (Figure 3) with a primary reinforcement of $600 \mathrm{kN} / \mathrm{m}$ and a secondary reinforcement of $300 \mathrm{kN} / \mathrm{m}$ with a 50 $\mathrm{cm}$ spacing of the geogrid named PARALINK ${ }^{\circledR}$ from the company called Maccaferri. According to the manufacturer, the 600 and the $300 \mathrm{kN} / \mathrm{m}$ PARALINK ${ }^{\circledR}$ geogrid has, respectively, a weight of approximately 1.66 and $0.85 \mathrm{Kg} / \mathrm{m}^{2}$. For the designed RSS, an area of $37.5 \mathrm{~m}^{2}$ is necessary for the primary reinforcement and $17.5 \mathrm{~m}^{2}$ for the secondary reinforcement for every 1 meter of structure length. 


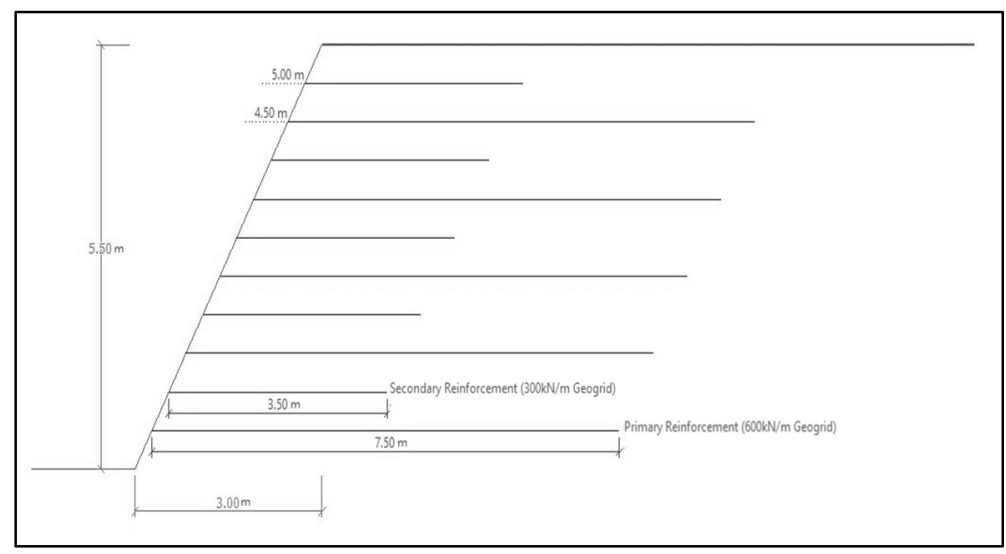

Figure 3: Designed RSS.

For the MSE wall (Figure 4) only a primary reinforcement of PARALINK ${ }^{\circledR} 600 \mathrm{kN} / \mathrm{m}$ is necessary resulting in an area of $63 \mathrm{~m}^{2}$ for reinforcement for every 1 meter of structure length. However, an MSE wall requires a system to protect its facing, so for the designed MSE in this research a system made of concrete blocks was proposed. The system consists of 28 units of $40 \times 20 \times 20 \mathrm{~cm}$ concrete blocks for every meter of structure length. To estimate the carbon dioxide emissions a value of $2.10 \mathrm{KG}$ of $\mathrm{CO}_{2}$ per block was used, which according to Oliveira et al. (2016) is the reference value in the related scientific literature for concrete blocks.

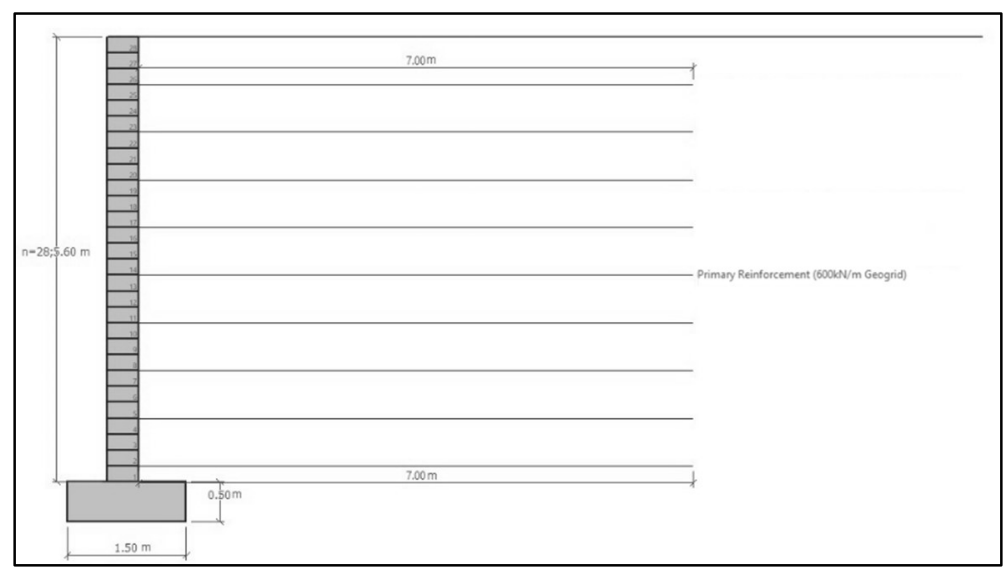

Figure 4: Designed MSE Wall.

Table 1 contains the results of the estimation of material volume necessary and $\mathrm{CO}_{2}$ emissions for each structure (MSE wall, RSS and Cantilever Wall proposed by Marchetti [2007]). Figure 5 is a graphic illustration comparing the estimated $\mathrm{CO}_{2}$ emissions in tons during the production of the materials necessary for each structure.

According to the results, the production process of concrete has the biggest influence on the $\mathrm{CO}_{2}$ emissions of retaining walls. The Reinforced Soil Slope (RSS) had the best results since it only uses geogrids in its system, establishing itself as a great alternative to the cantilever wall in order to reduce the carbon footprint of retaining walls. Besides having the best results, the RSS can also implement a vegetated facing, which can contribute to the biodiversity of the area through the increase of vegetated area leaving a positive impact on the landscape.

Options such as the MSE wall and RSS, are great tools to develop an adequate model of urban development since due to the rapid increase of urbanization after the Industrial Revolution, several 
settlements were created in unsuitable places with unstable terrain. He urbanization process happened at a rapid rate in Brazil during the 20th century reaching its peak between 1950 and 1980 and during its second half the urban population grew 7.33 times its size (BRITO et al., 2001).

Table 1: Necessary material volume and $\mathrm{CO}_{2}$ emissions for every 1 meter of structure length.

\begin{tabular}{|c|c|c|c|c|c|}
\hline TYPE & Material & Quantity & $\mathrm{Kg}$ of $\mathrm{CO} 2$ per Kg of Material & Total of $\mathrm{CO} 2$ emissions in $\mathrm{Kg}$ & $\%$ of the Total \\
\hline \multirow{2}{*}{$\begin{array}{l}\text { Reinforced concrete } \\
\text { cantilever wall proposed } \\
\text { by Marchetti (2007) }\end{array}$} & CA-50 Steel & $231.10 \mathrm{Kg}$ & 1.74 & 402.12096 & 0.047 \\
\hline & $20 \mathrm{MPa}$ Concrete & $7448.211 \mathrm{Kg}$ & 113.52 & 845520.913 & 99.953 \\
\hline \multirow{3}{*}{ Designed MSE Wall } & $\begin{array}{l}\text { Primary reinforcement } \\
\text { with a } 600 \mathrm{kN} / \mathrm{m} \text { geogrid }\end{array}$ & $104.58 \mathrm{~kg}$ & 2.97 & 310.6026 & 0.15 \\
\hline & \multicolumn{2}{|c|}{28 Blocks of concrete $(40 \times 20 \times 20)$} & $2.10 \mathrm{Kg}$ of $\mathrm{CO} 2$ per Block & 147 & 0.07 \\
\hline & $\begin{array}{l}\text { Foundation block using } 20 \\
\text { MPa concrete }(150 \times 50 \mathrm{~cm})\end{array}$ & $1805 \mathrm{Kg}$ & 113.52 & 204903.6 & 99.78 \\
\hline \multirow{2}{*}{ Designed RSS } & $\begin{array}{l}\text { Primary reinforcement } \\
\text { with a } 600 \mathrm{kN} / \mathrm{m} \text { geogrid }\end{array}$ & $62.25 \mathrm{Kg}$ & 2.97 & 184.8825 & 80.71 \\
\hline & $\begin{array}{l}\text { Secondary reinforcement } \\
\text { with a } 300 \mathrm{kN} / \mathrm{m} \text { geogrid }\end{array}$ & $14.88 \mathrm{Kg}$ & 2.97 & 44.17875 & 19.29 \\
\hline
\end{tabular}

Source: Adapted from Hammond et al. (2011), Marchetti (2007), Raja et al. (2015) and Oliveira et al. (2016).

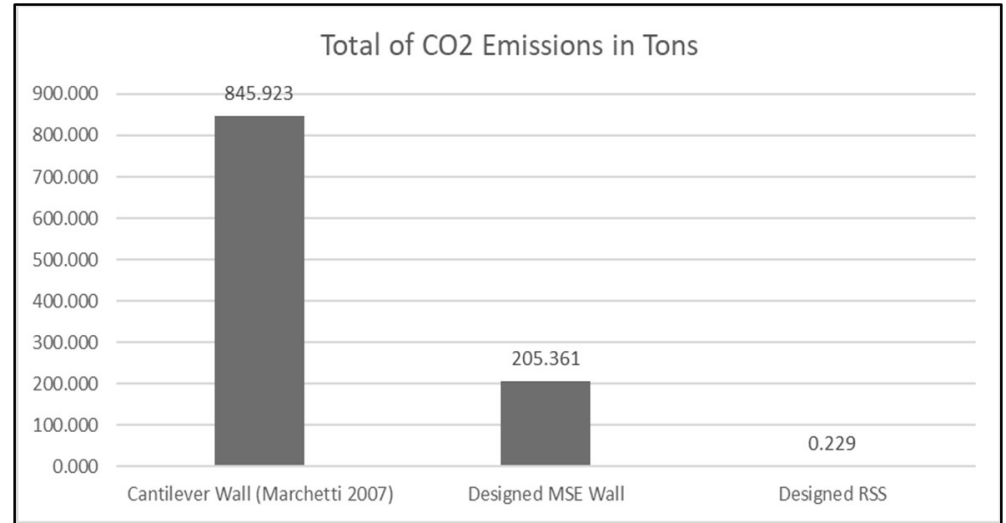

Figure 5: Graphic comparing the estimated $\mathrm{CO}_{2}$ emissions from each structure for 1 meter of structure length.

The lack of adequate urban planning in several municipalities of Brazil made the occupation process occurred in a disordered way, creating several social, environmental and infrastructural problems. One of the most common problem was the removal of vegetation cover from slopes and their subsequent occupation by often precarious housing, especially in medium to large cities. This problem exposed the soil, which initially helped to increase surface runoff, however, it also increased the risk of a landslide (SANTANA, 2018).

In short, the absence of an adequate model for urban development, led to the several communities settling in inappropriate places like unstable slopes and areas that should be environmentally protected like natural springs. According to Lee et al. (2018) areas with a higher populational density, like cities, increase the damages caused by landslides, especially due to the fact that it increases the probability of loss of life. Landslides are responsible for $15,60 \%$ of the loss of life from natural disasters in Brazil (UFSC et al., 2013). 
According to Almeida et al. (2017), this type of disaster causes huge negative economic and social impacts, like damages to the infrastructure.

Disordered urban expansion creates the need to develop tools aimed to relocate settlements away from unstable areas, or to stabilize the terrain in existent settlements. Thus, there is an increasing need for retaining walls in order to prevent landslides in these communities and reinforced soil structures are a great alternative to common methods, since they provide several benefits to the landscape when a vegetated facing is used, such as a smaller carbon footprint when compared to common methods.

However, reinforced soil structures cannot be used in every scenario, since, due to their building mechanisms, they require a considerable amount of space in order to perform the necessary excavation to apply the backfill and its reinforcement. When space is limited, conventional methods become the only possible solution since they don't need so much space to be built. However, when possible to build, soil reinforced structures bring several advantages to the environment they should be prioritized due to their lower carbon footprint and the fact that they can lead to an increase of vegetated area.

Monahan et al. (2011) describes an increasing interest in the comparison of carbon footprints for constructions utilizing alternative materials and methods. This interest is the result of society's increasing concern about the consequences of climate change, and it drives the development of innovative researches aimed at improving the construction sector with a sustainable vision.

Since 1990, newly industrialized countries have drastically increased their $\mathrm{CO}_{2}$ emissions from energy consumption compared to industrialized countries and the deterioration of environmental quality has reached alarming levels and has raised concerns about global warming and climate change (KASMAN et al., 2015). Considering that the construction sector is recognized worldwide as one of the major culprits of environmental contamination (PASSUELLO et al., 2014), it is paramount that countries focus on researching new construction techniques and materials that aim to reduce and mitigate $\mathrm{CO}_{2}$ emissions, drastically reducing the sector's impacts on natural ecosystems and human activities.

\section{CONCLUSIONS}

Urban expansion must occur in conjunction with an adequate model for urban development, whose main objectives must be to ensure a high quality of life for the population and to promote ways to mitigate environmental impacts caused by the expansion of the urban area. In this context, retaining walls act as a mechanism to stabilize terrain that can then be occupied by adequate housing. However, due to the lack of adequate urban planning in Brazil, there is an increasing need to stabilize terrain that has already been occupied. Reinforced soil structures are a great alternative with a smaller carbon footprint, when compared to conventional methods. They can also implement vegetation in their design bringing several benefits to the landscape of the biodiversity of the area.

Development of construction methods that have a smaller impact on the environment are essential to ensure that cities can grow in a sustainable way. When viable, the application of soil reinforced by geogrids can stabilize terrain in a less impactful way to the environment and can become a great tool for the 
development of adequate urban development models, focused on preserving the environment and ensuring a high quality of life to the population.

ACKNOWLEDGEMENTS: to the Coordination for the Improvement of Higher Education Personnel (CAPES) for their scholarship funding which was essential for this research.

\section{REFERENCES}

ALMEIDA, S.; HOLCOMBE, E. A.; PIANOSI, F.; WAGENER, T.. Dealing with deep uncertainties in landslide modelling for disaster risk reduction under climate change. Natural Hazards and Earth System Sciences, v.17, n.2, p.225-241, 2017. DOI: https://doi.org/10.5194/nhess-17-225-2017

ABNT. Associação Brasileira de Normas Técnicas. NBR 11682/2006. Estabilidade de encostas. ABNT: Rio de Janeiro, 2006.

AZAMBUJA, R. N.; CORRÊA, A. C. B.. Geomorfologia e áreas de expansão urbana do município de Garanhuns-PE: uma abordagem espaço-temporal dos eventos morfodinâmicos para o planejamento territorial. GEO UERJ, Rio de Janeiro, n.27, p.202-233, 2015. DOI:

https://doi.org/10.12957/geouerj.2015.16739

BERG, R. R.; CHRISTOPHER, B. R.; SAMTANI, N. C.. Design of mechanically stabilized earth walls and reinforced soil slopes. 2 ed. Washington: Federal Highway Administration, 2009.

BRITO, F.; HORTA, C. J. G.; AMARAL, E. F. L.. A urbanização recente no Brasil e as aglomerações metropolitanas. Open Science Framework Preprints, 2001. DOI: https://doi.org/10.31219/osf.io/84b92

CHOU, S.-S.; YEH, K.-C.. Life cycle carbon dioxide emissions simulation and environmental cost analysis for building construction. Journal of Cleaner Production, v.101, p.137147, 2015. DOI:

https://doi.org/10.1016/j.jclepro.2015.04.001

DARWIN, D.; DOLAN, C. W.; NILSON, A. H.. Design of concrete structures. 15 ed. New York: McGraw Hill Education, 2016.

HASSOUN, M. N.; AL-MANASEER, A.. Structural concrete: theory and design. 6 ed. Hoboken: Wiley, 2015.

KASMAN, A.; DUMAN, Y. S.. CO2 emissions, economic growth, energy consumption, trade and urbanization in new EU member and candidate countries: A panel data analysis. Economic Modelling, v.44, p.97-103, 2015. DOI: https://doi.org/10.1016/j.econmod.2014.10.022

LEE, S.; LEE, M.; LEE, S.. Spatial prediction of urban landslide susceptibility based on topographic factors using boosted trees. Environmental Earth Sciences, v.77, n.18, 2018. DOI: https://doi.org/10.1007/s12665-018-7778-7

MARANDOLA JÚNIOR, E.; MARQUES, C.; PAULA, L. T.; CASSANELI, L. B.. Crescimento urbano e áreas de risco no litoral norte de São Paulo. Revista Brasileira de Estudos de População, Belo Horizonte, v.30, n.2, p.35-56, 2013. DOI: http://dx.doi.org/10.1590/S0102-30982013000100003

MARCHETTI, O.. Muros de arrimo. São Paulo: Blucher, 2007.

MONAHAN, J.; POWELL, J. C.. An embodied carbon and energy analysis of modern methods of construction in housing: A case study using a lifecycle assessment framework. Energy and Buildings, v.43, n.1, p.179-188, 2011. DOI: https://doi.org/10.1016/i.enbuild.2010.09.005

PASSUELLO, A. C. B.; OLIVEIRA, A. F.; COSTA, E. B.; KIRCHHEIM, A. P.. Aplicação da avaliação do ciclo de vida na análise de impactos ambientais de materiais de construção inovadores: estudo de caso da pegada de carbono de clínqueres alternativos. Ambiente Construído, Porto Alegre, v.14, n.4, p.7-20, 2014. DOI: http://dx.doi.org/10.1590/S1678-86212014000400002

SANTANA, J. K. R.; LISTO, F. L. R.. Alterações morfológicas de encostas e deflagração de escorregamentos em áreas densamente urbanizadas: uma análise evolutiva em uma sub-bacia do município de Recife (PE). Revista de Geografia, Recife, v.35, n.3, 2018.

SANTORO, J. F.; KRIPKA, M.. Determinação das emissões de dióxido de carbono das matérias primas do concreto produzido na região norte do Rio Grande do Sul. Ambiente Construído, Porto Alegre, v.16, n.2, p.35-49, 2016. DOI: http://dx.doi.org/10.1590/s1678-86212016000200078

HAMMOND, G.; JONES, C.. Inventory of Carbon and Energy (ICE) V2.0. Bath: University of Bath, 2011.

RAJA, J.; DIXON, N.; FOWMES, G.; FROST, M.; ASSINDER, P.. Obtaining reliable embodied carbon values for geosynthetics. Geosynthetics International, v.22, n.5, p.393401, 2015. DOI: https://doi.org/10.1680/jgein.15.00020

OLIVEIRA, L. S.; PACCA, S. A.; JOHN, V. M.. Variability in the life cycle of concrete block $\mathrm{CO} 2$ emissions and cumulative energy demand in the Brazilian Market. Construction and Building Materials, v.114, p.588-594, 2016. DOI: https://doi.org/10.1016/j.conbuildmat.2016.03.134

UFSC. Universidade Federal de Santa Catarina; CEPED. Centro Universitário de Estudos e Pesquisas sobre Desastres. Atlas brasileiro de desastres naturais: 1991 a 2012. 2 ed. Florianópolis: UFSC: Curitiba: CEPED, 2013.

$\mathrm{XIAO}, \mathrm{M}$. . Geotechnical Engineering Design. Chichester: Wiley, 2015.

A CBPC - Companhia Brasileira de Produção Científica (CNPJ: 11.221.422/0001-03) detém os direitos materiais desta publicação. Os direitos referem-se à publicação do trabalho em qualquer parte do mundo, incluindo os direitos às renovaç̃̃es, expansões e disseminações da contribuição, bem como outros direitos subsidiários. Todos os trabalhos publicados eletronicamente poderão posteriormente ser publicados em coletâneas impressas sob coordenação da Sustenere Publishing da Companhia Brasileira de Produção Científica e seus parceiros autorizados. Os (as) autores (as) preservam os direitos autorais, mas não têm permissão para a publicação da contribuição em outro meio, impresso ou digital, em português ou em tradução. 